Article

\title{
Performance of an Automated Zika IgG Immunoassay in the Detection of Zika IgG Specific Antibodies-A Validation Approach in Samples from Prevalence Areas and Non-Endemic Countries
}

\author{
Tina Laengin, Stephanie Augenstein, Elke Stadlbauer, Heike Girgnhuber, Mario Gloeck and \\ Alexander Riedel * \\ Centralised and Point of Care Solutions, Roche Diagnostics GmbH, D-82377 Penzberg, Germany; \\ tina.laengin@roche.com (T.L.); stephanie.lepa@roche.com (S.A.); elke.stadlbauer@roche.com (E.S.); \\ heike.girgnhuber@roche.com (H.G.); mario.gloeck@roche.com (M.G.) \\ * Correspondence: alexander.ridel@roche.com
}

Received: 5 March 2020; Accepted: 1 June 2020; Published: 8 June 2020

\begin{abstract}
The diagnosis of Zika virus infection is complicated and includes testing for nucleic acids and IgM and IgG antibodies, depending on the stage of infection. Zika IgG is an important marker of infection after the acute stage; however, IgG assays can lack specificity due to the similarities between Zika and other flaviviruses. In this study, the diagnostic sensitivity and specificity of the Elecsys ${ }^{\circledR}$ Zika IgG assay were assessed in 496 samples from Zika endemic regions, and specificity only was assessed in 1685 blood screening and diagnostic samples from Zika non-endemic regions. Cross-reactivity was also assessed against a panel of 202 potentially cross-reacting samples. The performance of the Elecsys ${ }^{\circledR}$ Zika IgG assay was compared with the anti-Zika virus ELISA IgG. In the samples from the Zika endemic regions, the Elecsys ${ }^{\circledR}$ Zika IgG assay had $92.88 \%$ (95\% confidence interval 89.42-95.48) sensitivity and $100 \%$ specificity and in the samples from Europe the Elecsys ${ }^{\circledR}$ Zika IgG assay specificity was $\geq 99.62 \%$. The Elecsys ${ }^{\circledR}$ Zika IgG assay was highly specific in samples from both prevalent and non-endemic regions.
\end{abstract}

Keywords: Zika virus; serology; diagnosis; immunoglobulin; sensitivity; specificity

\section{Introduction}

The Zika virus (ZIKV) is a mosquito-borne flavivirus that was first isolated in 1947 from a febrile rhesus macaque in the Zika forest of Uganda through a yellow fever surveillance network in the area [1]. The following year, the ZIKV was isolated from Aedes mosquitoes from the same forest [2]. The first human case of infection with ZIKV occurred in Uganda in 1962-3 [3]. Recently, the virus has become more widely known due to a series of epidemics starting in Micronesia in 2007 and the eventual emergence of ZIKV in Brazil in 2014 [4]. Since then, the ZIKV has spread considerably in the Americas and has also been reported in Europe [4,5].

Transmission of the virus to humans is primarily through the bite of an infected Aedes mosquito species, although transmission may also occur through several non-vector-borne routes, including pre- and peri-natal transmission, sexual intercourse, and blood transfusions [6-8]. The increasing worldwide presence of the Aedes mosquito species may lead to the emergence of new ZIKV epidemics in urban areas [9].

ZIKV infection is asymptomatic in an estimated $80 \%$ of cases [10-12]. When symptomatic, ZIKV infection usually presents with non-specific influenza-like symptoms, including rash, fever, arthralgia, myalgia, headache, and conjunctivitis, typically lasting 3-6 days $[10,12]$. Infections may be clinically 
difficult to distinguish from diseases caused by other arboviruses including Dengue virus (DENV), Chikungunya, and West Nile virus [9].

Complications of ZIKV infection include Guillain-Barré syndrome, a neurologic disorder that can lead to paralysis and death [9]. Pre-natal ZIKV infection can cause serious neurologic sequelae including, but not limited to, microcephaly, ventriculomegaly, intracranial calcifications, and ocular abnormalities [8].

Laboratory evidence of ZIKV infection can be obtained by testing clinical samples (biofluids and tissue) for viral nucleic acid or virus-specific IgM and IgG antibodies [12]. Serologic testing is recommended in individuals if the specimen is collected more than 1 week after the onset of symptoms [13]. Due to the clinical manifestations and the associated consequences, diagnostic requests in those countries at the highest risk of a ZIKV outbreak are forecast to increase substantially [14]. The ZIKV shares a considerable degree of structural homology with other flaviviruses $[15,16]$. Serology-based diagnosis has historically posed a challenge due to the well-known problem of potential cross-reactivity with antibodies produced, particularly against other flaviviruses including DENV [12].

Currently, there are neither vaccines to prevent Zika nor effective drugs for the treatment of already infected patients [17]. Improvements in the surveillance and monitoring of Zika infection would support the efforts to combat this viral infection [17].

Due to the similarity of ZIKV to other viruses, the Elecsys ${ }^{\circledR}$ Zika IgG assay was developed as a highly specific assay to limit cross-reaction and reduce the occurrence of false-positive results. The objective of this study was to evaluate the specificity of the Elecsys ${ }^{\circledR}$ Zika IgG assay, a qualitative one-step double-antigen sandwich (DAGS) immunoassay using recombinant ZIKV antigens, designed for the in vitro detection of anti-Zika IgG antibodies in human serum and plasma, using samples from: ZIKV prevalence areas, blood donors from Europe, pregnant women from Europe, and samples from other viral, bacterial, and parasitic infections.

\section{Methods}

\subsection{Study Design}

This was an analytical performance evaluation of the Elecsys ${ }^{\circledR} \mathrm{Zika} \mathrm{IgG}$ assay using the cobas $\mathbf{e}$ 601 platform. The performance of the Elecsys ${ }^{\circledR}$ Zika IgG assay was compared with that of the anti-Zika virus ELISA IgG (EUROIMMUN, Lübeck, Germany) [18]. Testing of the Elecsys ${ }^{\circledR}$ Zika IgG was performed at TRIGA-S Scientific Solutions, Habach, Germany. All other testing was performed at Roche Diagnostics GmbH (Penzberg, Germany).

\subsection{Samples}

Frozen serum/plasma specimens from different populations from prevalent and non-endemic regions were used to assess the specificity of the Elecsys ${ }^{\circledR}$ Zika IgG assay. Samples from prevalent areas included patients from Latin America with suspected Zika infection $(\mathrm{N}=396)$ and patients in the Côte d'Ivoire $(\mathrm{N}=100)$. Samples from non-endemic countries included presumed negative samples from Latin America (collected prior to Zika epidemics; $N=94$ ), samples from pregnant women from Europe $(\mathrm{N}=500)$, blood donors from Europe $(\mathrm{N}=532)$, and blood donors from tick-borne encephalitis (TBE) endemic regions with high TBE vaccination coverage $(\mathrm{N}=559)$. All samples were obtained from the following commercial vendors: Medical Research Networx LLC, Biomex AG, Blood-Bank Innsbruck, Teragenix Inc., Biomex AG, TrinaBioreactives AG, Agencia Nacional de Vigilancia Sanitaria, and Roche Molecular Diagnostics, Indianapolis. The study was conducted according to the study protocol provided by Roche Diagnostics and in accordance with the Declaration of Helsinki: patient samples were fully anonymized, leftover samples that were obtained with signed informed consent and were preserved for research use. 
For the analytical specificity analysis, samples that were positive for non-Zika infections $(\mathrm{N}=202)$ were also commercially obtained as described above.

\subsection{Methods and Analyses}

The sensitivity and specificity of the Elecsys ${ }^{\circledR}$ Zika IgG assay were determined using a testing algorithm: the comparator serologic test, followed by further resolution of any discrepant samples using blocking experiments (using Zika/Dengue full length NS1 protein) and/or the recomLINE Tropical Fever IgG immunoblot assay (MIKROGEN GmbH, Neuried, Germany; Figure 1) [19]. The testing algorithm provided a surrogate standard for assessing diagnostic performance. Diagnostic specificity, diagnostic sensitivity, and confidence intervals ((CI) 95\%, two-sided) were calculated using a validated statistical analysis system (SAS) tool (developed by Biostatistics, Roche Diagnostics GmbH).

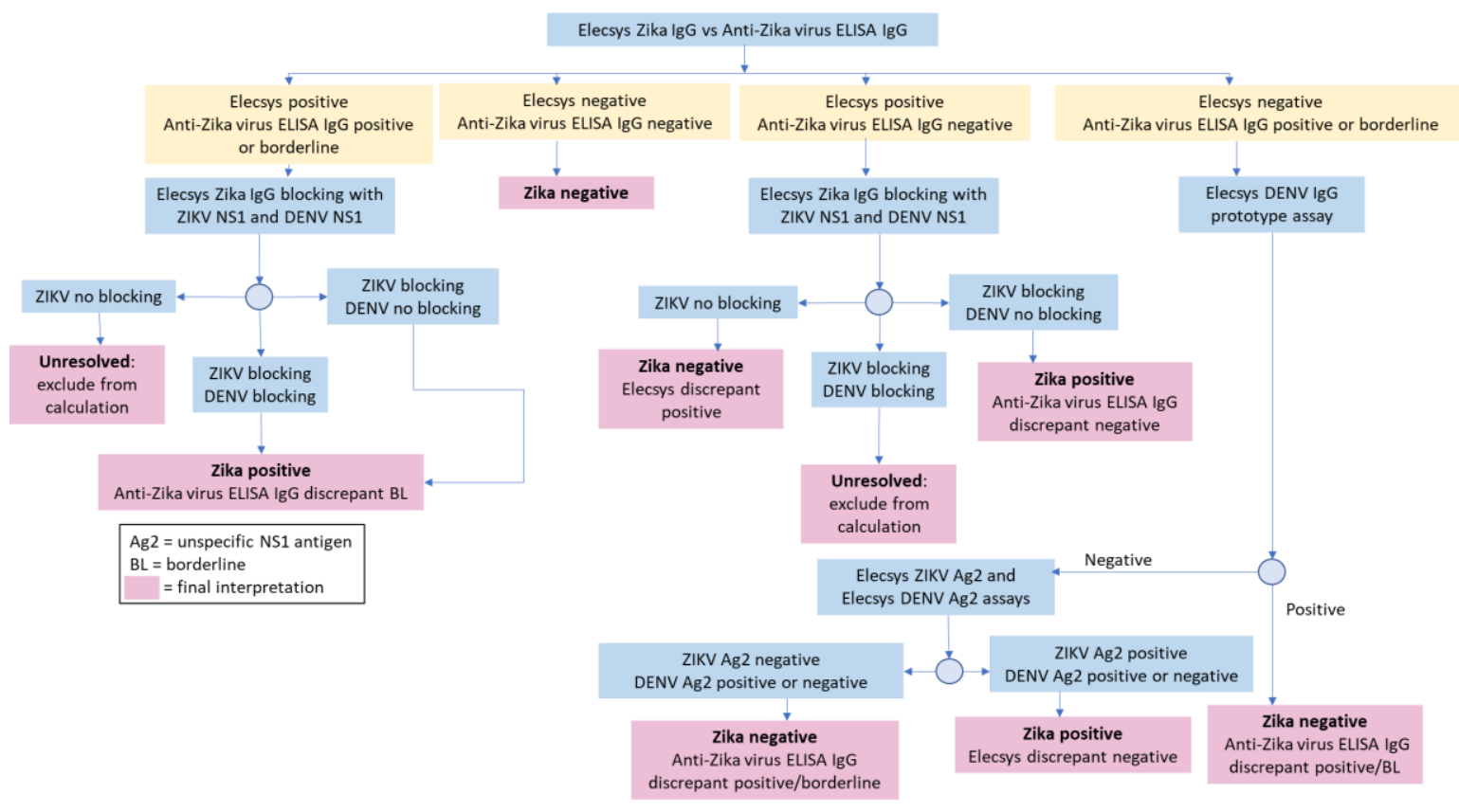

Figure 1. Resolution testing algorithm.

\section{Results}

\subsection{Diagnostic Performance}

\subsubsection{Zika Endemic Areas}

The Elecsys ${ }^{\circledR}$ Zika IgG assay was assessed in a total of 496 samples from ZIKV endemic areas. In these samples, the Elecsys ${ }^{\circledR}$ Zika IgG assay had $100 \%$ specificity, correctly determining 151 Zika-negative samples (Table 1). The 99 samples that were determined negative by both the Elecsys ${ }^{\circledR}$ Zika IgG assay and the anti-Zika virus ELISA IgG were not further tested and did not need resolution. In total, 52 samples that were confirmed negative by resolution testing were either reactive or borderline with the anti-Zika virus ELISA IgG which had 65.56\% (95\% CI, 57.40-73.10) specificity.

To assess the sensitivity of the Elecsys ${ }^{\circledR}$ Zika IgG assay compared with the anti-Zika virus ELISA IgG, the 397 samples that were either concordant positive or discordant were further tested with the resolution algorithm (Figure 1). The Elecsys ${ }^{\circledR}$ Zika IgG assay identified 287 of the 309 positive samples and was $92.88 \%$ (95\% CI, 89.42-95.48) sensitive. The anti-Zika virus ELISA IgG identified all 309 samples as Zika positive or borderline and was 100\% (95\% CI, 98.81-100) sensitive. Of the 22 samples that were Elecsys ${ }^{\circledR}$ Zika IgG negative but discrepant, further testing found that 10 were positive for DENV IgG antibodies, 10 were positive for flavivirus IgGs and two samples remained inconclusive. 
Table 1. Elecsys ${ }^{\circledR}$ Zika IgG and anti-Zika virus ELISA IgG assay diagnostic sensitivity and specificity in samples from endemic areas.

\begin{tabular}{|c|c|c|c|c|c|c|c|}
\hline Cohort & $\mathbf{N}$ & $\begin{array}{l}\text { Positive or } \\
\text { Borderline } \\
\text { * Samples } \\
\text { after } \\
\text { Resolution }\end{array}$ & $\begin{array}{l}\text { Negative } \\
\text { Samples } \\
\text { after } \\
\text { Resolution }\end{array}$ & $\begin{array}{l}\text { Unresolved } \\
\text { Samples }\end{array}$ & $\begin{array}{c}\text { Negative } \\
\text { Discrepant } \\
\text { Samples after } \\
\text { Resolution }^{+}\end{array}$ & $\begin{array}{c}\text { Sensitivity } \\
\text { (95\% CI) }\end{array}$ & $\begin{array}{l}\text { Specificity } \\
(95 \% \text { CI) }\end{array}$ \\
\hline \multicolumn{8}{|c|}{ Elecsys $^{\circledR}$ Zika IgG } \\
\hline $\begin{array}{l}\text { Suspected } \\
\text { Zika } \\
\text { infection } \\
\text { from Latin } \\
\text { America }\end{array}$ & 396 & 284 & 55 & 36 & 21 & $\begin{array}{c}93.11 \\
(89.67-95.69)\end{array}$ & $\begin{array}{c}100 \\
(93.51-100)\end{array}$ \\
\hline $\begin{array}{l}\text { Samples } \\
\text { from Côte } \\
\text { d'Ivoire }\end{array}$ & 100 & 3 & 96 & 0 & 1 & $\begin{array}{c}75.00 \\
(19.41-99.37)\end{array}$ & $\begin{array}{c}100 \\
(96.23-100)\end{array}$ \\
\hline Total & 496 & 287 & 151 & 36 & 22 & $\begin{array}{c}92.88 \\
(89.42-95.48)\end{array}$ & $\begin{array}{c}100 \\
(97.59-100)\end{array}$ \\
\hline \multicolumn{8}{|c|}{ Anti-Zika Virus ELISA IgG } \\
\hline $\begin{array}{l}\text { Suspected } \\
\text { Zika } \\
\text { infection } \\
\text { from Latin } \\
\text { America }\end{array}$ & 396 & 305 & 21 & 36 & 34 & $\begin{array}{c}100.00 \\
(98.80-100)\end{array}$ & $\begin{array}{c}38.18 \\
(25.41-52.27)\end{array}$ \\
\hline $\begin{array}{l}\text { Samples } \\
\text { from Côte } \\
\text { d'Ivoire }\end{array}$ & 100 & 4 & 78 & 0 & 18 & $\begin{array}{c}100 \\
(39.76-100)\end{array}$ & $\begin{array}{c}81.25 \\
(72.00-88.49)\end{array}$ \\
\hline Total & 496 & 309 & 99 & 36 & 52 & $\begin{array}{c}100 \\
(98.81-100)\end{array}$ & $\begin{array}{c}65.56 \\
(57.40-73.10)\end{array}$ \\
\hline
\end{tabular}

* Only the anti-Zika virus ELISA IgG had borderline results. ${ }^{\dagger}$ There were no positive discrepant samples after resolution testing.

\subsubsection{Zika Non-Endemic Regions}

In 1685 routine diagnostic and blood screening samples from Europe, the Elecsys ${ }^{\circledR}$ Zika IgG assay had a specificity of $99.88 \%$ (95\% CI, 99.57-99.99) (Table 2). The specificity was $100 \%$ in most groups and only differed in the general European blood donor group. Specificity was not reduced in patients from the high TBE vaccination status group. Due to the small number of Zika-positive samples in this cohort, it was not appropriate to assess the assay sensitivity.

Table 2. Elecsys ${ }^{\circledR}$ Zika IgG assay diagnostic specificity in samples from non-endemic areas.

\begin{tabular}{|c|c|c|c|c|c|}
\hline Cohort & $\mathbf{N}$ & $\begin{array}{c}\text { Positive } \\
\text { Samples after } \\
\text { Resolution }\end{array}$ & $\begin{array}{c}\text { Negative } \\
\text { Samples after } \\
\text { Resolution }\end{array}$ & $\begin{array}{l}\text { Positive Discrepant } \\
\text { Samples after } \\
\text { Resolution }\end{array}$ & $\begin{array}{l}\text { Specificity } \\
(95 \% \text { CI) }\end{array}$ \\
\hline $\begin{array}{l}\text { Samples from Latin } \\
\text { America before Zika } \\
\text { epidemics }\end{array}$ & 94 & 2 & 92 & 0 & $100(96.07-100)$ \\
\hline $\begin{array}{l}\text { Pregnant women in } \\
\text { Europe }\end{array}$ & 500 & 0 & 500 & 0 & $100(99.26-100)$ \\
\hline European blood donors & 532 & 4 & 526 & 2 & $\begin{array}{c}99.62 \\
(98.64-99.95)\end{array}$ \\
\hline $\begin{array}{c}\text { European blood donors } \\
\text { with high TBE } \\
\text { vaccination status }\end{array}$ & 559 & 0 & 559 & 0 & $100(99.34-100)$ \\
\hline Total & 1685 & 6 & 1677 & 2 & $\begin{array}{c}99.88 \\
(99.57-99.99)\end{array}$ \\
\hline
\end{tabular}

\subsection{Analytical Specificity}

A total of 202 potentially cross-reacting samples, positive for other "non-Zika" infections, that were Zika-negative using the anti-Zika virus ELISA IgG were all also Zika-negative with the Elecsys ${ }^{\circledR}$ Zika IgG assay (Table 3). 
Table 3. Assessment of the Elecsys ${ }^{\circledR}$ Zika IgG assay in potentially cross-reacting samples.

\begin{tabular}{cccc}
\hline Pathogen & N & Non-Reactive & Reactive \\
\hline DENV & 30 & 30 & 0 \\
\hline Cytomegalovirus & 12 & 12 & 0 \\
\hline Epstein-Barr virus & 11 & 11 & 0 \\
\hline Herpes simplex virus & 10 & 10 & 0 \\
\hline Hepatitis A virus & 8 & 8 & 0 \\
\hline Rubella virus & 12 & 12 & 0 \\
\hline Hepatitis B virus & 11 & 11 & 0 \\
\hline Hepatitis C virus & 12 & 12 & 0 \\
\hline $\begin{array}{c}\text { Plasmodium } \\
\text { falciparum/vivax (malaria) }\end{array}$ & 11 & 11 & 0 \\
\hline Treponema pallidium \\
(syphilis)
\end{tabular}

\section{Discussion}

In this study, the specificity of the Elecsys ${ }^{\circledR}$ Zika IgG assay was high in all sample cohorts from endemic and non-endemic areas. This is important as cases of Zika are reported in both scenarios and also in the interest of being able to detect historic infection and to help predict future outbreaks of the disease [20,21]. The Center for Disease Control and Prevention currently advises caution against the potential cross-reactivity of Zika IgG assays [21]; however, in this study we found no cross-reactivity with any of the other infections that were assessed. The Elecsys ${ }^{\circledR}$ Zika IgG assay was also highly specific in patients with high vaccine status for TBE. In the samples from Zika endemic regions, there were no false positives using the Elecsys ${ }^{\circledR}$ Zika IgG assay and only two samples yielded false positives with the Elecsys ${ }^{\circledR}$ Zika IgG assay in this study. Further analysis of the negative Elecsys ${ }^{\circledR}$ Zika IgG discrepant samples from the Zika endemic region found that some were DENV positive or positive for general flavivirus. This suggests that the Elecsys ${ }^{\circledR}$ Zika IgG does not cross-react with DENV, which is a known problem for Zika IgG assays [22,23]. Like the anti-Zika virus ELISA IgG, the Elecsys ${ }^{\circledR}$ Zika IgG assay was designed to target antibodies to the ZIKV NS1 antigen; however, the Elecsys ${ }^{\circledR}$ Zika IgG assay targeted only the immunodominant wing domain in order to avoid cross-reactivity [24]. In addition to the specificity shown in this study, the sensitivity of the Elecsys ${ }^{\circledR}$ Zika IgG was $>92 \%$ and was similar to that of the anti-Zika virus ELISA IgG. This suggests that the specificity of the Elecsys ${ }^{\circledR}$ Zika IgG assay is not improved by compromising the sensitivity of the assay. This is important as commercially available Zika assays have been shown to have either low sensitivity or specificity in a clinical setting $[25,26]$.

Due to its persistence in the blood, Zika IgG is particularly useful for mapping patterns of infection and predicting future outbreaks and is used by the WHO in reporting and confirming outbreaks [13]. Zika IgG has also been found to be present in high levels in infants born with microcephaly, suggesting it might also be important in assessing maternal-fetal disease transmission [27]. This study demonstrates 
that the Elecsys ${ }^{\circledR}$ Zika IgG assay is highly specific and is a promising tool for use in monitoring Zika seroprevalence and infection.

Author Contributions: Conceptualization, M.G. and A.R.; Data curation, M.G.; Formal analysis, T.L., S.A., E.S. and M.G.; Funding acquisition, A.R.; Investigation, S.A., E.S., H.G., M.G. and A.R.; Methodology, M.G.; Project administration, T.L. and A.R.; Resources, S.A., E.S., M.G. and A.R.; Supervision, T.L. and A.R.; Validation, S.A. and E.S.; Visualization, A.R.; Writing - review \& editing, T.L., S.A., E.S., H.G. and A.R. All authors have read and agreed to the published version of the manuscript.

Funding: This research was funded by Roche Diagnostics GmbH.

Acknowledgments: This study was funded by Roche Diagnostics $\mathrm{GmbH}$ and the authors are employees of Roche Diagnostics. Marta Leis of TRIGA-S Solutions was the study investigator. Medical writing support was provided by Rose Falconer of Elements Communications, Westerham, UK and was funded by Roche Diagnostics GmbH.

Conflicts of Interest: This study was funded by Roche Diagnostics and the authors are employees of Roche Diagnostics.

\section{References}

1. Dick, G.W.; Kitchen, S.F.; Haddow, A.J. Zika virus. I. Isolations and serological specificity. Trans. R. Soc. Trop. Med. Hyg. 1952, 46, 509-520. [CrossRef]

2. Dick, G.W. Zika virus. II. Pathogenicity and physical properties. Trans. R. Soc. Trop. Med. Hyg. 1952, 46, 521-534. [CrossRef]

3. Simpson, D.I. Zika virus infection in man. Trans. R. Soc. Trop. Med. Hyg. 1964, 58, 335-338. [CrossRef]

4. Lowe, R.; Barcellos, C.; Brasil, P.; Cruz, O.G.; Honório, N.A.; Kuper, H.; Carvalho, M.S. The Zika virus epidemic in Brazil: From discovery to future implications. Int. J. Environ. Res. Public Health 2018, 15, 96. [CrossRef] [PubMed]

5. Spiteri, G.; Sudre, B.; Septfons, A.; Beauté, J.; The European Zika Surveillance Network. Surveillance of Zika virus infection in the EU/EEA, June 2015 to January 2017. Eurosurveillance 2017, 22, 17-00254. [CrossRef] [PubMed]

6. Paixăo, E.S.; Teixeira, M.G.; Rodrigues, L.C. Zika, chikungunya and dengue: The causes and threats of new and re-emerging arboviral diseases. BMJ Glob. Health 2018, 3, e000530. [CrossRef] [PubMed]

7. Musso, D.; Roche, C.; Robin, E.; Nhan, T.; Teissier, A.; Cao-Lormeau, V.M. Potential sexual transmission of Zika virus. Emerg. Infect. Dis. 2015, 21, 359-361. [CrossRef]

8. Vouga, M.; Baud, D. Imaging of congenital Zika virus infection: The route to identification of prognostic factors. Prenat. Diagn. 2016, 36, 799-811. [CrossRef]

9. Marano, G.; Pupella, S.; Vaglio, S.; Liumbruno, G.M.; Grazzini, G. Zika virus and the never-ending story of emerging pathogens and transfusion medicine. Blood Transfus. 2016, 14, 95-100.

10. Duffy, M.R.; Chen, T.H.; Hancock, W.T.; Powers, A.M.; Kool, J.L.; Lanciotti, R.S.; Pretrick, M.; Marfel, M.; Holzbauer, S.; Dubray, C.; et al. Zika virus outbreak on Yap Island, Federated States of Micronesia. N. Engl. J. Med. 2009, 360, 2536-2543. [CrossRef]

11. Ladhanim, S.N.; O'Connor, C.; Kirkbride, H.; Brooks, T.; Morgan, D. Outbreak of Zika virus disease in the Americas and the association with microcephaly, congenital malformations and Guillain-Barré syndrome. Arch. Dis. Child. 2016, 101, 600-602. [CrossRef] [PubMed]

12. Singh, R.K.; Dharma, K.; Karthik, K.; Tiwari, R.; Khandia, R.; Munjal, A.; Igbal, H.M.N.; Malik, Y.K.; Bueno-Mari, R. Advances in diagnosis, surveillance, and monitoring of Zika virus: An update. Front. Microbiol. 2018, 8, 2677. [CrossRef] [PubMed]

13. World Health Organization. Zika Epidemiology Update-July 2019. Available online: https://www.who.int/ emergencies/diseases/zika/zika-epidemiology-update-july-2019.pdf?ua=1 (accessed on 2 January 2020).

14. UNICEF Supply Division 2017. Zika Virus Diagnostics: Target Product Profiles \& Supply Update. Available online: https://www.unicef.org/supply/files/Zika_Virus_Diagnostics_Target_Product_Profile_and_Supply_ Note.pdf (accessed on 2 January 2020).

15. Prasad, V.M.; Miller, A.S.; Klose, T.; Sirohi, D.; Buda, G.; Jiang, W.; Kuhn, R.J.; Rossmann, M.G. Structure of the immature Zika virus at $9 \AA$ resolution. Nat. Struct. Mol. Biol. 2017, 24, 184-186. [CrossRef] [PubMed]

16. Sirohi, D.; Chen, Z.; Sun, L.; Klose, T.; Pierson, T.C.; Rossmann, M.G.; Kuhn, R.J. The 3.8 Å resolution cryo-EM structure of Zika virus. Science 2016, 352, 467-470. [CrossRef] 
17. Singh, R.K.; Dhama, K.; Khandia, R.; Munjal, A.; Kumaragurubaran, K.; Tiwari, R.; Chakraborty, S.; Malik, Y.S.; Bueno-Mari, R. Prevention and control strategies to counter Zika virus, a special focus on intervention approaches against vector mosquitoes-current updates. Front. Microbiol. 2018, 9, 87. [CrossRef] [PubMed]

18. EUROIMMUN. Zika Virus Infections EUROIMMUN Test Systems for the Diagnosis of Zika Virus Infections. Available online: https://www.euroimmun.com/documents/Indications/Infections/Zika-virus/HI_2668_I_ UK_B.pdf (accessed on 2 January 2020).

19. Mikrogen Diagnostik. recomLin Tropical Fever IgG. Available online: https://www.mikrogen.de/english/ deutschland/products/product-overview/testsystem/tropical-fever-igg.html (accessed on 2 January 2020).

20. Petersen, L.R.; Jamieson, D.J.; Powers, A.M.; Honein, M.A. Zika virus. N. Engl. J. Med. 2016, 374, $1552-1563$. [CrossRef] [PubMed]

21. Centers for Disease Control and Prevention. Testing for Zika Virus Infections. Available online: https: //www.cdc.gov/zika/laboratories/types-of-tests.html (accessed on 2 January 2020).

22. Landry, M.L.; St George, K. Laboratory diagnosis of Zika virus infection. Arch. Pathol. Lab. Med. 2017, 141, 60-67. [CrossRef]

23. Fritzell, C.; Rousset, D.; Adde, A.; Kazanji, M.; Van Kerkhove, M.D.; Flamand, C. Current challenges and implications for dengue, chikungunya and Zika seroprevalence studies worldwide: A scoping review. PLoS Negl. Trop. Dis. 2018, 12, e0006533. [CrossRef]

24. Xu, X.; Song, H.; Qi, J.; Liu, Y.; Wang, H.; Su, C.; Shi, Y.; Gao, G.F. Contribution of intertwined loop to membrane association revealed by Zika virus full-length NS1 structure. EMBO J. 2016, 35, 2170-2178. [CrossRef]

25. Kikuti, M.; Tauro, L.B.; Moreira, P.S.S.; Campos, G.S.; Paploski, I.A.D.; Weaver, S.C.; Mitermayer, G.R.; Kitron, U.; Ribeiro, G.S. Diagnostic performance of commercial IgM and IgG enzyme-linked immunoassays (ELISAs) for diagnosis of Zika virus infection. Virol. J. 2018, 15, 108. [CrossRef]

26. Safronetz, D.; Sloan, A.; Stein, D.R.; Mendoza, E.; Barario, N.; Ranandheera, C.; Scharikow, L.; Holloway, K.; Robinson, A.; Traykova-Andonova, M.; et al. Evaluation of 5 commercially available Zika Virus immunoassays. Emerg. Infect. Dis. 2017, 23, 1577-1580. [CrossRef] [PubMed]

27. Rosenstierne, M.W.; Schaltz-Buchholzer, F.; Bruzadelli, F.; Có, A.; Cardoso, P.; Jørgensen, C.S.; Michiels, J.; Heyndrickx, L.; Ariën, K.K.; Fischer, T.K.; et al. Zika virus IgG in infants with microcephaly, Guinea-Bissau, 2016. Emerg. Infect. Dis. 2018, 2, 948-950. [CrossRef] [PubMed] 